\title{
RUANG KREATIF DAN REKREASI DI PASAR BARU
}

\author{
Kevin Liong ${ }^{1)}$, Martin Halim²) \\ 1)Program Studi S1 Arsitektur, Fakultas Teknik, Universitas Tarumanagara, Kevinliong79@gmail.com \\ 2) Program Studi S1 Arsitektur, Fakultas Teknik, Universitas Tarumanagara, Martinhalim90@gmail.com
}

\begin{abstract}
Abstrak
Sebagai makhluk sosial, manusia amatlah membutuhkan ruang interaksi. Dimana ruang interaksi ini dapat menjadi latar bagi perkembangan kehidupan, baik dalam kegiatan ekonomi, sosial dan juga hiburan. Kurangnya ruang interaksi yang layak mengakibatkan masyarakat mengatasinya secara mandiri. Pada Kelurahan Pasar Baru didapati permasalahan dalam hal penyediaan fasilitas ruang interaksi serta permasalahan pada pengangguran usia produktif. Sehingga dalam rancangan akan fokus pada kedua permasalahan tersebut. Secara garis besar rancangan program pada Ruang Kreatif dan Rekreasi dibagi menjadi dua yaitu program utama yang bersifat rekreasi dan program penunjang yang bersifat edukasi, dimana program utama merupakan program rekreasi yang mengakomodir kebutuhan masyarakat akan ruang interasksi sosial yang juga mewadahi usaha mikro kecil menengah yang dijalani masyarakat pada sektor usaha kuliner dengan membuat area kuliner. Kemudian program penunjang yang berupa fasilitas edukasi, akan memfasilitasi masyarakat terhadap akses pendidikan informal yang akan menambah keahlian masyarakat melalui pelatihan industri kreatif terutama bidang fashion dan kria yang didasarkan pada konsentrasi industri yang ada di Pasar Baru dimana produk fashion dan kria ini dapat mudah ditemui disini. Selain itu program edukasi juga menawarkan industri perfilman sebagai salah satu program edukasi yang ditawarkan.
\end{abstract}

Kata kunci: ekonomi; interaksi; keahlian

\begin{abstract}
As social beings, humans really need space for interaction. This interaction space can be a background for the development of life, both in economic, social and entertainment activities. Lack of appropriate interaction space causes the community to handle it independently. In the Pasar Baru community there are problems in terms of providing interaction space facilities as well as problems in the productive age unemployment. So in this project will focus on these two problems. The program design in the Creative Recreative Place is divided into two, recreational program and educational support program, where the recreational program accommodates the community's need for social interaction space which also accommodates micro, small and medium businesses undertaken by the community in culinary business sector by creating a culinary area. Then the support program which consists of education, will facilitate the public access to informal education that will increase community expertise through creative industry training, especially in fashion and handicraft which is based on the concentration of industries in Pasar Baru where fashion and handicraft products can be easily found here. In addition, the education program also places the film industry as one of the educational programs offered.
\end{abstract}

Keywords: economy; expertise; interaction

\section{PENDAHULUAN Latar Belakang}

Kota Jakarta telah menjadi sebuah kota yang memiliki daya tarik ekonomi tinggi dengan program pembangunan infrastruktur yang cukup masif. Namun program pengembangan infrastruktur serta daya magnet ekonomi ini memiliki masalah bagi masyarakat. Pengembangan infrastruktur 
ini agaknya melupakan bahwa masyarakat dalam berkembang juga memerlukan ruang sosial. Pembangunan yang ada amatlah kurang pada penyediaan fasilitas ruang interaksi sosial bagi masyarakat. Kebutuhan ruang interaksi dibutuhkan masyarakat dimana ruang interaksi ini dapat menjadi latar bagi perkembangan kehidupan, baik dalam kegiatan ekonomi, sosial dan juga hiburan.

\section{Rumusan Permasalahan}

Pada survey ditemukan permasalahan yang terjadi di tengah masyarakat kelurahan Pasar Baru, terutama wilayah Krekot. Permasalahan yang terjadi diantaranya kurangnya tempat yang layak bagi masyarakat untuk berkumpul dan juga permasalahan pengangguran. Permasalahan pengguran ini menarik dimana banyak masyarakat yang menganggur merupakan lulusan SMK.

\section{Tujuan}

Atas dasar masalah yang ada tersebut, proyek dibentuk dengan tujuan meningkatkan kemampuan serta daya saing masyarakat serta memberikan masyarakat akses ruang berkumpul yang inklusif, ruang bermain yang layak dan juga sarana hiburan masyarakat.

\section{KAJIAN LITERATUR}

\section{Open Architecture}

Open Architecture menurut Herman Hertzberger ialah banyak hal yang dilakukan dengan empati, ketika kebanyakan arsitek terlalu sibuk dengan struktur bangunan namun tidak dengan manusianya. third place sendiri berarti a living room of society, dimana memiliki ciri fisik dan non fisik. Ciri fisiknya seperti transparan, memiliki void guna adanya antar hubungan, aksesibilitas dan porositas. Untuk ciri non fisiknya berupa program aktivitas, adanya placeness dan juga playfulness.

\section{Third Place}

Menurut Ray Oldenburg pengertian third place sendiri adalah tempat untuk orang mengobati strees, kesepian dan keterasingan. Pada third place orang melarikan diri dari first place dan second place untuk bersosialisai, bersantai dan juga mendapatkan ketenangan di dalamnya. Third place menurut Oldenburg memiliki 8 karakter yaitu netral dimana pengunjung dari third place tidak memiliki kewajiban untuk hadir disana, kesejajaran yang berarti tidak mementingkan status individu dalam partisipasinya, percakapan ringan sebagai aktivitas utama, terbuka juga accessible untuk pengguna, memiliki penghuni rutin sebagai pembuat karakteristik, menerima segala macam individu dari berbagai latar belakang, suasana yang menyenangkan dengan percakapan ringan dan dapat menjadi tempat yang memiliki perasaan hangat seperti di rumah sendiri.

Menurut Board \& Vellum, terkadang third place terjadi secara tidak sengaja. Orang mungkin menemukan ruang acak yang menawarkan pemandangan unik, atau sudut di ruang publik dengan pertimbangan privasi dapat menjadikanya sebuah third place. Ada beberapa aspek yang biasanya diharapkan orang terhadap third place seperti tempat duduk dan aktivitas yang nyaman, kebisingan yang rendah, serta interior yang mengundang yang menawarkan keseimbangan antara privasi dengan koneksi visual lainya. Menurut Caleb Bertels, third place merupakan tempat yang mampu menampung banyak kegiatan serta memberikan kesempatan untuk berinteraksi, menyampaikan informasi, dan bertukar barang dan jasa. Manusia merupakan makhluk yang memiliki kebutuhan dan keinginan yang berubah, yang berarti kualitas tempat ketiga harus beradaptasi juga jika mereka ingin terus menarik orang. 


\section{Pemberdayaan}

Menurut Suhendra dalam buku Peran Birokrasi dalam Pemberdayaan Masyarakat, pemberdayaan adalah "suatu kegiatan yang berkesinambungan, dinamis, secara sinergis mendorong keterlibatan semua potensi yang ada secara evolutif dengan keterlibatan semua potensi". Selain itu menurut Widjaja dalam buku Otonomi Desa Merupakan Otonomi Asli Bulat dan Utuh, pemberdayaan masyarakat merupakan sebuah upaya dalam meningkatkan kemampuan dan potensi yang dimiliki masyarakat, sehingga masyarakat dapat mewujudkan jati diri, harkat dan martabatnya secara maksimal untuk bertahan dan mengembangkan diri secara mandiri baik di bidang ekonomi, sosial, agama dan budaya. Kartasasmita dalam buku Pemberdayaan Masyarakat Sebuah Tinjauan Administrasi, mengemukakan bahwa upaya memberdayakan rakyat harus dilakukan melalui tiga cara yakni menciptakan suasana atau iklim yang memungkinkan potensi masyarakat untuk berkembang, memperkuat potensi yang dimiliki oleh masyarakat dengan menerapkan langkah-langkah nyata seperti menampung berbagai masukan serta menyediakan prasarana dan sarana yang lebih baik dan juga memberdayakan masyarakat dalam arti melindungi dan membela kepentingan masyarakat yang lemah.

\section{METODE}

\section{Pengumpulan Data}

Pengumpulan data merupakan prosedur guna memperkuat ide dasar yang didapatkan secara lang sung maupun tidak langsung. Dalam melakukan perancangan penulis melakukan pengumpulan data berupa kondisi eksisiting lingkungan dan juga fenomena yang terjadi dalam masyarakat melalui penerapan metode pengumpulan data baik primer maupun sekunder yang kemudian akan dianalisis baik dari segi tapak, fungsi pada bangunan, pengguna, ruang dan juga bentuk rancangan melalui proses metode analisis.

\section{Data Primer}

Data primer merupakan data yang diperoleh secara langsung melalui survey pengamatan lokasi serta wawancara dengan warga setempat. Survey pengamatan lokasi dan kawasan dilakukan mulai dari halte bus Transjakarta Pasar Baru dilanjutkan pada kawasan perbelanjaan Pasar Baru dan kemudian pada kawasan pemukiman pada kelurahan Pasar Baru. Survey dan pengamatan yang dilakukan meliputi aktivitas dan alur pergerakan masyarakat dan juga pemasalahan yang terjadi pada masyarakat. Untuk melengkapi dan memperkuat survey dan pengamatan yang dilakukan secara visual, penulis melakukan wawancara dengan masyarakat di area perbelanjaan maupun area pemukiman.

\section{Data Sekunder}

Data sekunder merupakan data yang didapat secara tidak langsung dari data Badan Pusat Statistika DKI Jakarta dan Jakarta Satu. Data ini digunakan untuk memperkuat data primer yang sebelumnya telah didapatkan melalui survey pengamatan dan wawancara pada masyarakat. Data yang dikumpulkan merupakan data dominasi usia penduduk dan juga data pekerjaan yang kemudian digabungkan dan diolah kembali guna menghasilkan data yang memperkuat data primer yang ada.

\section{Metode Analisis}

Analisis merupakan proses pengamatan yang berdasarkan kriteria tertentu sehingga dapat melahirkan solusi yang bersifat ilmiah. Beberapa analisis yang dilakukan dalam perancangan arsitektur, diantaranya;

a. Analisis tapak, yang membahas mengenai masalah dan kondisi eksisting tapak.

b. Analisis fungsi bangunan, membahas baik fungsi utama dan penunjang bangunan.

c. Analisis pengguna, yang membahas pengguna bangunan mulai dari pengunjung sampai karyawanya dan juga aktivitas yang dilakukannya. 
d. Analisis ruang, yang membahas karakteristik dan standar ruang bangunan yang dirancang.

e. Analisis bentuk, yang membahas bentuk fisik bangunan sesuai dengan kondisi lingkungan tapak dan juga konsep terpilih.

\section{DISKUSI DAN HASIL}

Perancangan bangunan ini terbagi menjadi beberapa konsep hasil dari analisis yang dilakukan meliputi analisis tapak, analisis fungsi bangunan, analisis pengguna, analisis ruang dan juga analisis konsep dan bentuk perancangan berikut dengan penerapannya.

\section{Analisis tapak}

Tapak dipilih merupakan tapak yang berada dekat dengan pemukiman masyarakat serta menjadi lintasan pergerakan masyarakat dari first place menuju second place. Pada kawasan pemukiman sekitar tapak dijumpai permasalahan dalam masyarakat dalam hal penyediaan ruang interaksi dan juga pengagguran pada usia produktif. Berdasarkan hasil survey dan pengamatan yang dilakukan pada saat siang hari ditengah pemukiman RW 05 warga tampak berkumpul untuk sekedar membaca koran, berbincang ataupun bermain catur.

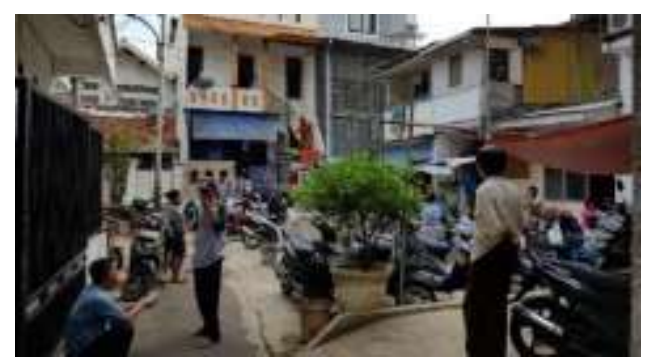

Gambar 2. Area berkumpul warga saat ini Sumber: Dokumen pribadi

Kemudian jika melihat pada data BPS Jakarta, Kelurahan Pasar Baru sendiri memiliki 15373 penduduk dengan dominasi pada usia produktif kemudian di ikuti usia dibawah 15 tahun dilanjutkan dengan usia lansia. Dilihat dari sektor pekerjaan penduduk kelurahan Pasar baru, sebanyak 2116 jiwa belum atau tidak bekerja, sementara sisanya bekerja pada banyak sektor. Dengan angka tersebut Kelurahan Pasar Baru memiliki rasio penduduk tidak bekerja yang lebih besar dibanding dengan kelurahan lain di kecamatan yang sama.

Tabel 1. Rasio jumlah penduduk yang tidak bekerja dengan jumlah penduduk

\begin{tabular}{|c|c|c|c|}
\hline Kelurahan & $\begin{array}{c}\text { Jumlah tidak/belum } \\
\text { bekerja }\end{array}$ & $\begin{array}{l}\text { Jumlah } \\
\text { Penduduk }\end{array}$ & Rasio \\
\hline Pasar Baru & 2116 & 15817 & $13,4 \%$ \\
Gunung Sahari Utara & 2514 & 20600 & $12,2 \%$ \\
Kartini & 3692 & 28178 & $13,1 \%$ \\
Karang Anyar & 4462 & 33540 & $13,3 \%$ \\
Mangga Dua Selatan & 5021 & 34944 & $14,3 \%$ \\
\hline
\end{tabular}

Sumber : BPS Jakarta

Tapak yang dipilih sebagai tempat berdirinya rancangan ini memiliki akses terhadap jalan Krekot Bunder Raya, Jalan Lautze, dan juga Jalan Krekot. Tapak memiliki bentuk trapesium dengan luas 1960 meter persegi. Untuk peraturan bangunannya tapak memiliki koefisien dasar bangunan sebesar 60, dengan koefisien luas bangunan sebesar 2.4, dan ketinggian bangunan yang diizinkan sebanyak empat lapis. 


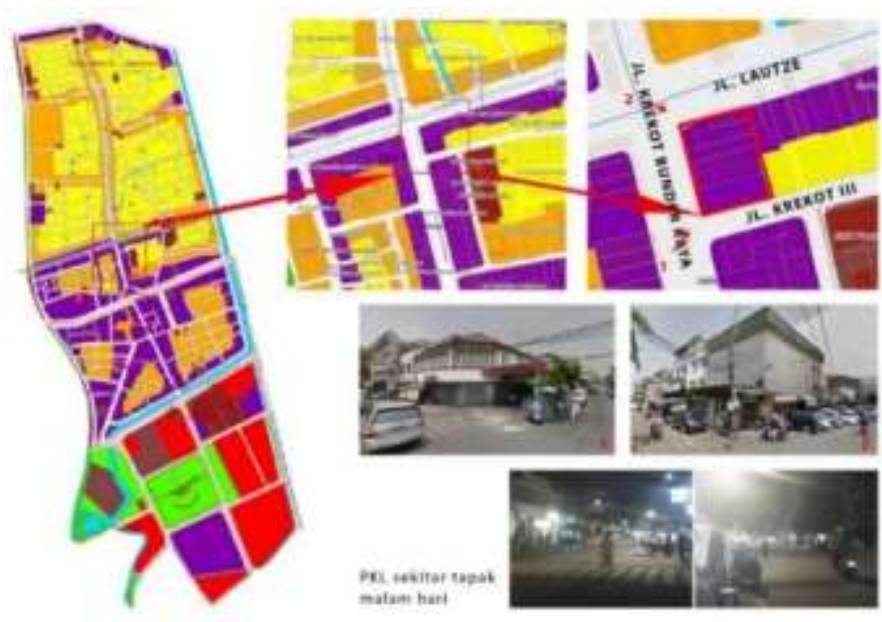

Gambar 3. Peta lokasi tapak dan kondisi eksisting Sumber: Data Jakarta Satu yang diolah penulis

\section{Analisa sirkulasi dan parkir}

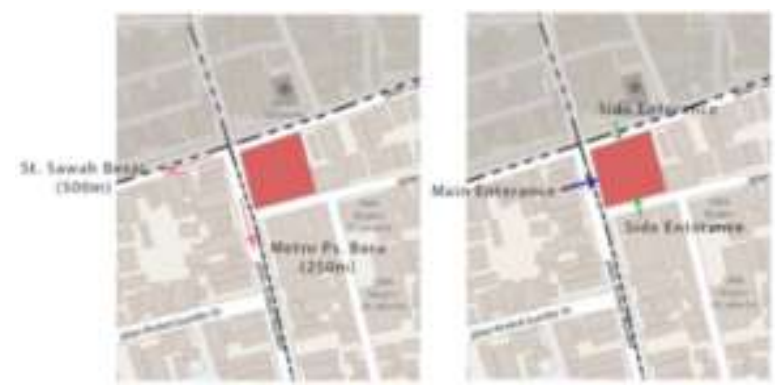

Gambar 4. Diagram analisis pencapaian

Sumber: Data Jakarta Satu yang diolah penulis

Tapak berada di Jalan Krekot Bunder Raya dengan lalu lintas dua arah, dimana pada sepanjang sisi jalan ini terdapat on street parking sehingga pada tapak tidak perlu menyediakan tempat parkir. Sebagai enterance utama dirancang menghadap Jalan Krekot Bunder Raya, sementara tetap menyediakan akses melalui Jalan Krekot 3 dan Jalan Lautze yang mana dapat menjadi akses utama bagi masyarakat sekitar.

\section{Analisis orientasi dan vegetasi}

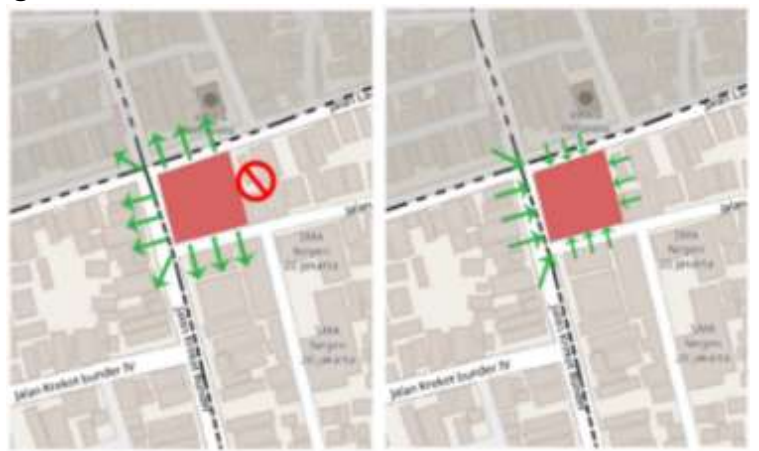

Gambar 5. Diagram analisis pencapaian

Sumber: Data Jakarta Satu yang diolah penulis

Orientasi bangunan difokuskan pada Jalan Krekot Bunder Raya, Jalan Krekot 3 dan juga Jalan Lautze mengarah kedalam tapak. Dikarekana minimnya vegetasi sekitar tapak, rancangan juga berkonsep menyediakan ruang hijau disekitar tapak dan juga pada titik tengah rancangan. 
Analisis kebisingan

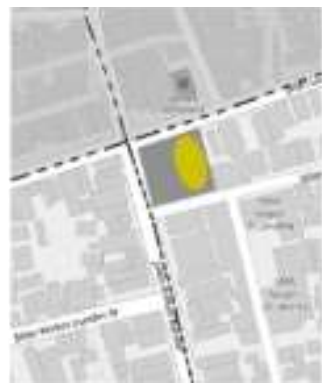

Gambar 6. Diagram analisis kebisingan

Sumber: Data Jakarta Satu yang diolah penulis

Tapak berada di lokasi yang sekitarnya terdapat kegiatan komersil perdagangan, dimana pada siang hari cukup bising oleh kegiatan bongkar muat barang, oleh karena itu area yang perlu ketenangan lebih diletakan pada bagian belakang tapak.

Analisis banjir

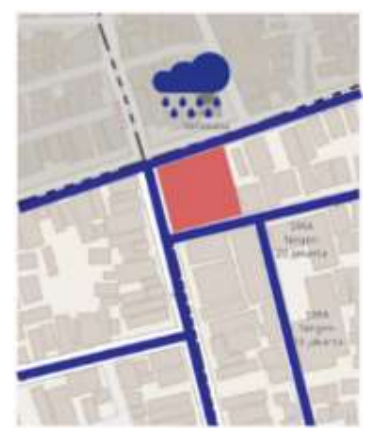

Gambar 7. Diagram analisis banjir

Sumber: Data Jakarta Satu yang diolah penulis

Sekitar tapak memiliki saluran air yang bermuara di sungai ciliwung sehingga saat ketinggian air sungai sedang tinggi aliran air tidak dapat bergerak kearah sungai. Hal ini mengakibatkan lokasi ini sering terjadi banjir. Sebagai tanggapan terhadap kondisi banjir yang sering melanda, ketinggian rancangan akan ditinggikan dari ketinggian jalan, sementara untuk pekerasan menggunakan pavingblock yang memungkinkan genangan air dapat terserap kedalam tanah.

\section{Analisis fungsi bangunan}

Rancangan program pada Creative Recreative Place dibagi menjadi dua yaitu program utama yang bersifat rekreasi dan program penunjang yang bersifat edukasi. Pada program rekreasi terdapat program kuliner dan area berkumpul sementara untuk program edukasi akan dilengkapi dengan area pelatihan dan toko kerajinan tangan.

\section{Area kuliner}

Gerai makanan yang ada merupakan kegiatan usaha mikro kecil menengah masyarakat sehingga program ini akan berkontribusi terhadap pengembangan usaha kecil masyarakat dalam bidang kuliner.

\section{Area berkumpul}

Area berkumpul yang dirancang bagi masyarakat agar masyarakat dapat berkumpul dengan rasa nyaman dan aman. Tempat duduk pada area ini berbagi koneksi visual dengan eksterior dengan tidak menutup pandangan kearah luar. Tempat ini juga memiliki board game untuk keluarga atau orang lain yang hanya ingin menghabiskan waktu dan berkomunikasi satu sama lain. 


\section{Edukasi}

Program edukasi meliputi program workshop industri kreatif terutama bidang industri fashion dan juga kria serta bidang perfilman, dan juga area galeri serta penjualan hasil produksi. Program yang ada merupakan program tidak berbiaya yang bebas diikuti masyarakat. Kemudian untuk fasilitas produksi disini digunakan masyarakat yang sudah terampil untuk berproduksi dimana hasil produksinya dapat dipamerkan di galeri ataupun diperjualbelikan di toko kerajinan yang ada. Pada area produksi memungkinkan adanya masyarakat melihat dan berinteraksi langsung dengan pembuat produk. Sehingga menciptakan program produksi yang interaktif dimana area produksi ini juga menjadi area edukasi selain workshop.

\section{Analisis konsep}

Rancangan menerapkan konsep bangunan hijau yang memiliki efisiensi terhadap penggunaan energi. Sehingga rancangan dibuat hampir sepenuhnya terbuka dan memiliki akses pada ruang luar. Selain itu massa bangunan juga membuat courtyard dalam bangunan guna mempermudah sirkulasi angin. Rancangan yang terbuka memaksimalkan pengudaraan alami yang akan berkontribusi pada penurunan penggunaan ac.

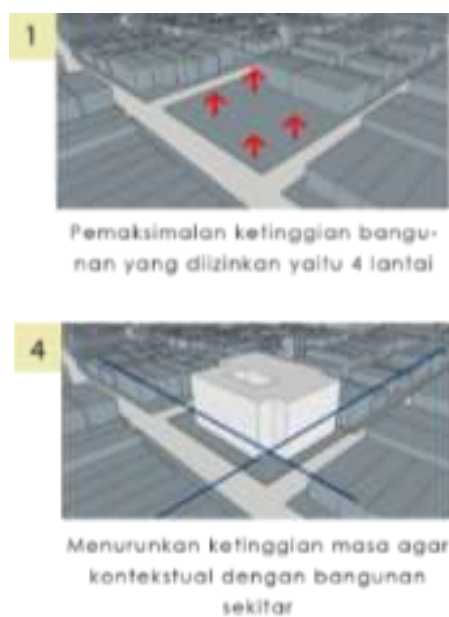

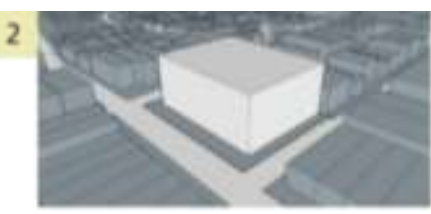

Membuat courtyard sebagai orien. tasi dalam bangunan dan juga mempermudah sirkulasi angin

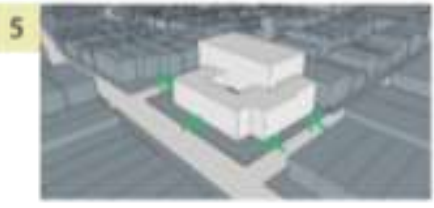

Membuka bagian bawah sebagai enterance masuk bangunan

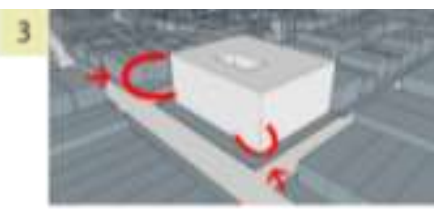

Memenudurkan masa sebagal te. spons terhadop per empatan dor per tigaan jalan

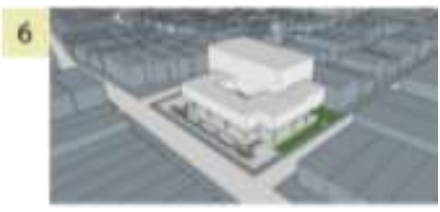

Gambar 8. Diagram proses gubahan massa

Sumber: dokumen pribadi

Untuk bentuk massa rancangan bangunan menerapkan desain rancangan yang merespons terhadap kondisi lingkungan sekitar serta dengan blok massa lingkungan, sehingga rancangan yang dihadirkan tidak menjadi benda asing bagi lingkungan melainkan menjadi satu konteks dengan lingkungan kawasan.

\section{Analisis pengguna}

Pengguna rancang bangunan dibagi menjadi tiga bagian yaitu masyarakat yang ikut produksi, pengunjung umum baik yang ingin mengikuti workshop maupun hanya untuk makan dan minum, dan juga pekerja staff dan pengajar. Berikut merupakan diagram skema aktivitas dari tiap pengguna bangunan (Diagram 1).

\section{Analisis ruang}

Analisis ruang akan menjelaskan kondisi ruang dari bangunan yang akan dirancang, meliputi karakteristik bangunan serta kebutuhan ruang yang ada. Berikut merupakan tabel kebutuhan ruang (Tabel 2). 


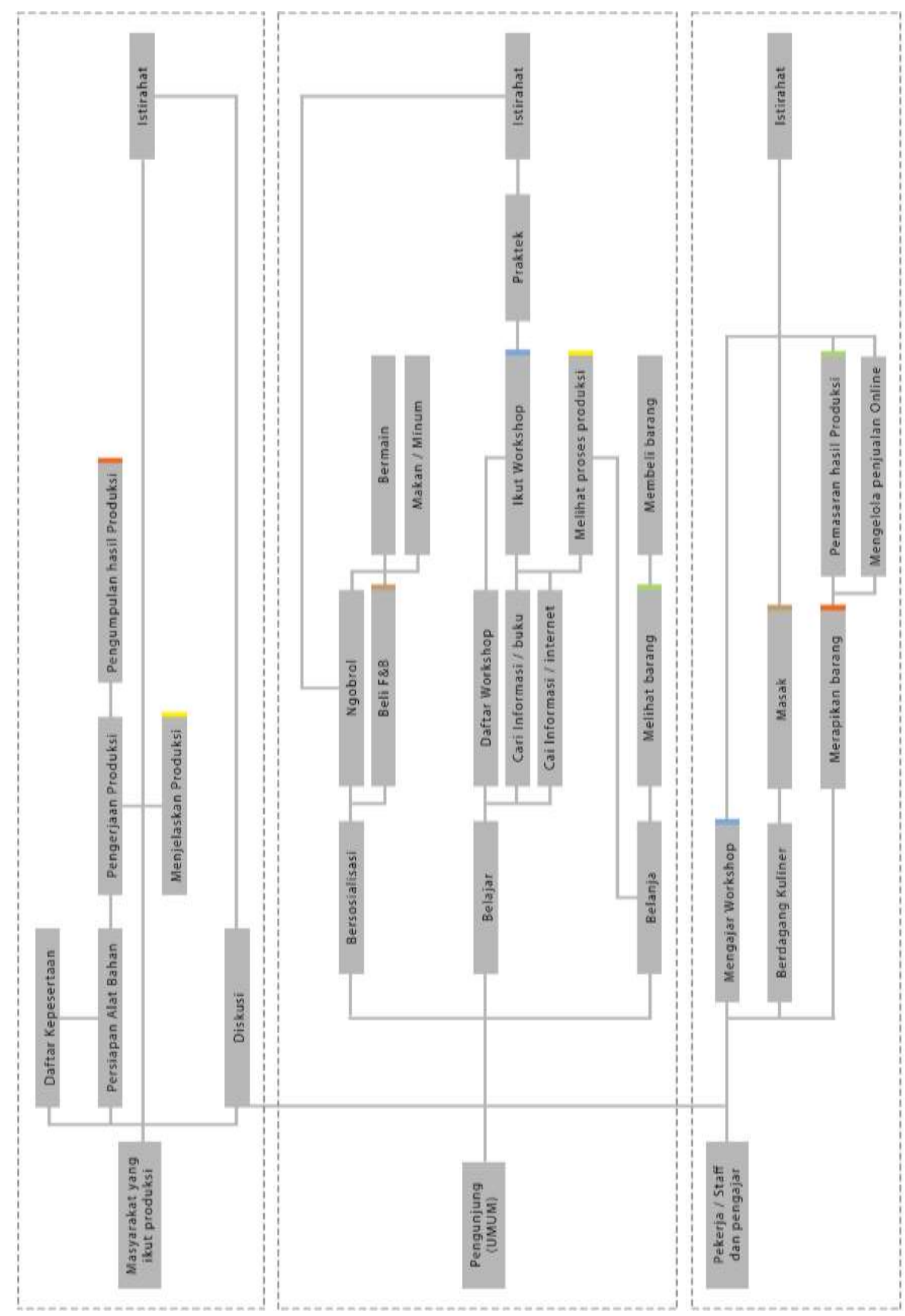



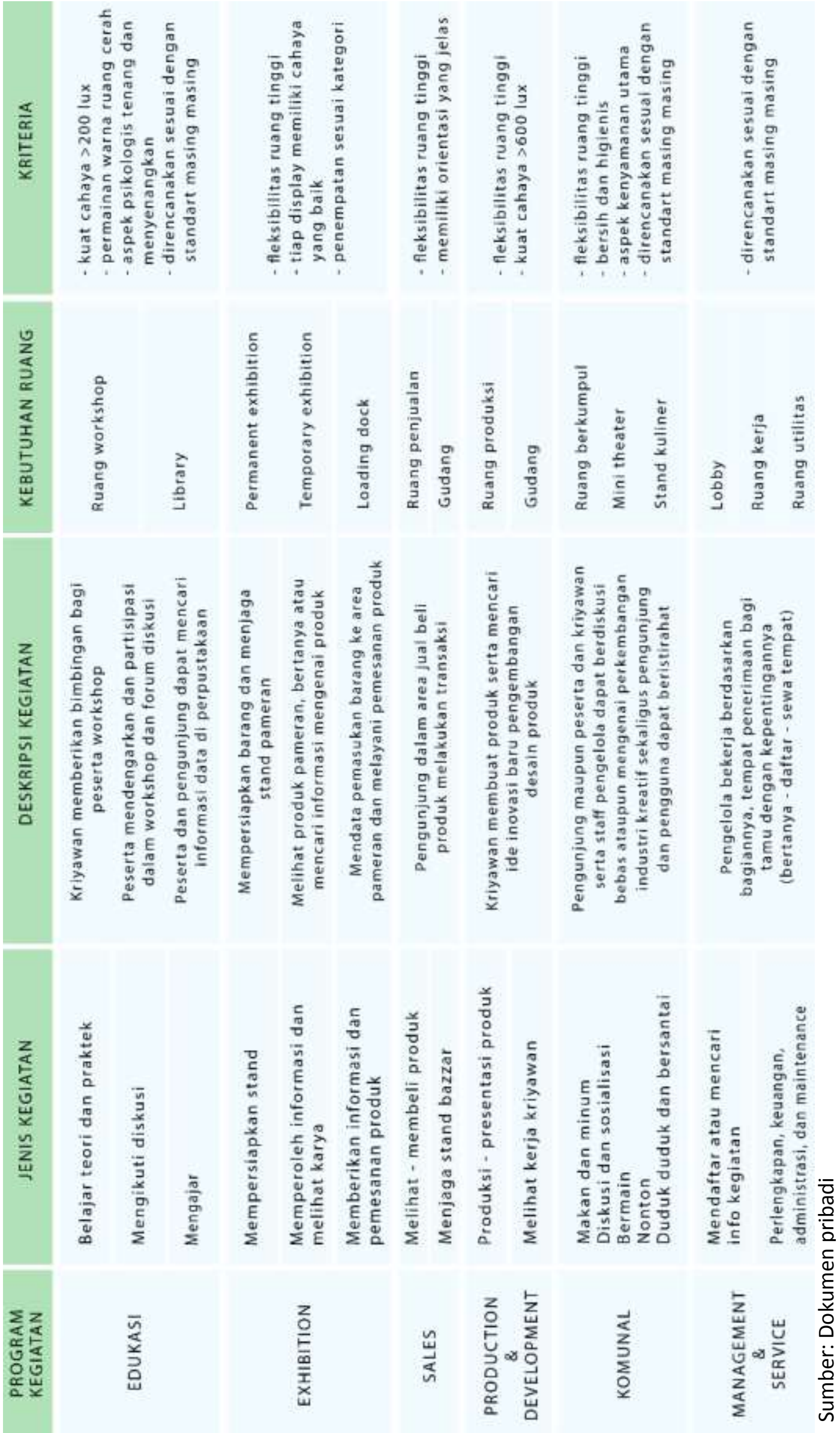


\section{Analisis preseden serta penerapan hasil analisis pada desain}

Dalam melakukan perancangan, penulis juga melakukan pendekatan perancangan melalui studi preseden. Proses studi preseden dilakukan pada Kyoto Handicraft Center, INDOESTRI, dan juga 8th Street Market. Dari tiap preseden ini akan ditarik benang merah yang akan menjadi konsep ide dalam perancangan ini.

\section{Kyoto Handicraft Center}

Keunikan yang terdapat pada Kyoto Handicraft Center adalah arus sirkulasi pengunjung dimualai dari lantai teratas. Sehingga pengunjung akan berkenalan dan belajar mengenai seni kerajinan tangan terlebih dahulu kemudian dibawa turun ke lantai berikutnya yang menjual produk produk kerajinan.

\section{Indoestri}

Keunikan pada preseden ini terletak pada rancangan desain ruang workshop yang terbuka yang memungkinkan adanya interaksi antar pengguna dari kegiatan yang berbeda. Poin lain yang akan diambil ialah pengaturan penggunaan ruang yang maksimal dimana pada Senin hingga Jumaat mereka gunakan untuk para member sementara untuk hari Sabtu digunkan untuk kursus.

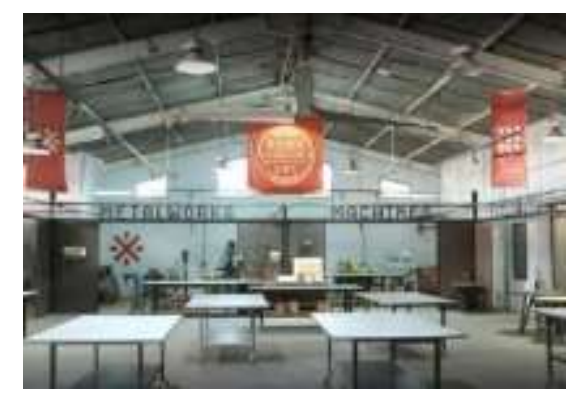

Gambar 9. Ruang workshop komunal

Sumber: indoestri.com

\section{8th Street Market}

8th Street Market ini menjadi preseden untuk setting interior untuk kegiatan dalam third place, dimana tempat ini merupakan tempat hiburan bagi masyarakat. Pada 8th Street Market sendiri terbagi menjadi beberapa kelompok program yaitu food truck pada area outdoor dan The Holler yang merupakan café yang dilengkapi dengan area bermain berupa arcade game dan juga area shuffleboard.

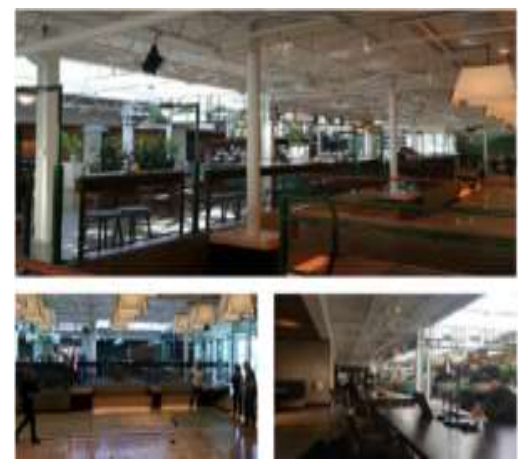

Gambar 10. Area café yang digabung dengan area bermain Sumber: Decoding Third Place, 2019:118

Dari ketiga preseden tersebut akan memberikan input terhadap desain perancangan ini dimana pada Kyoto Handicraft Center akan mengambil pola public viewing systemnya yang memungkinkan masyarakat terlebih dahulu melihat proses produksi untuk kemudian diarahkan ke lantai dibawahnya yaitu area toko dan juga restoran. Dari preseden ini juga akan mengambil 
konsep yang dapat memberikan edukasi kepada pengunjung dengan memperbolehkan pengunjung belajar secara langsung dengan para kriawan disana.

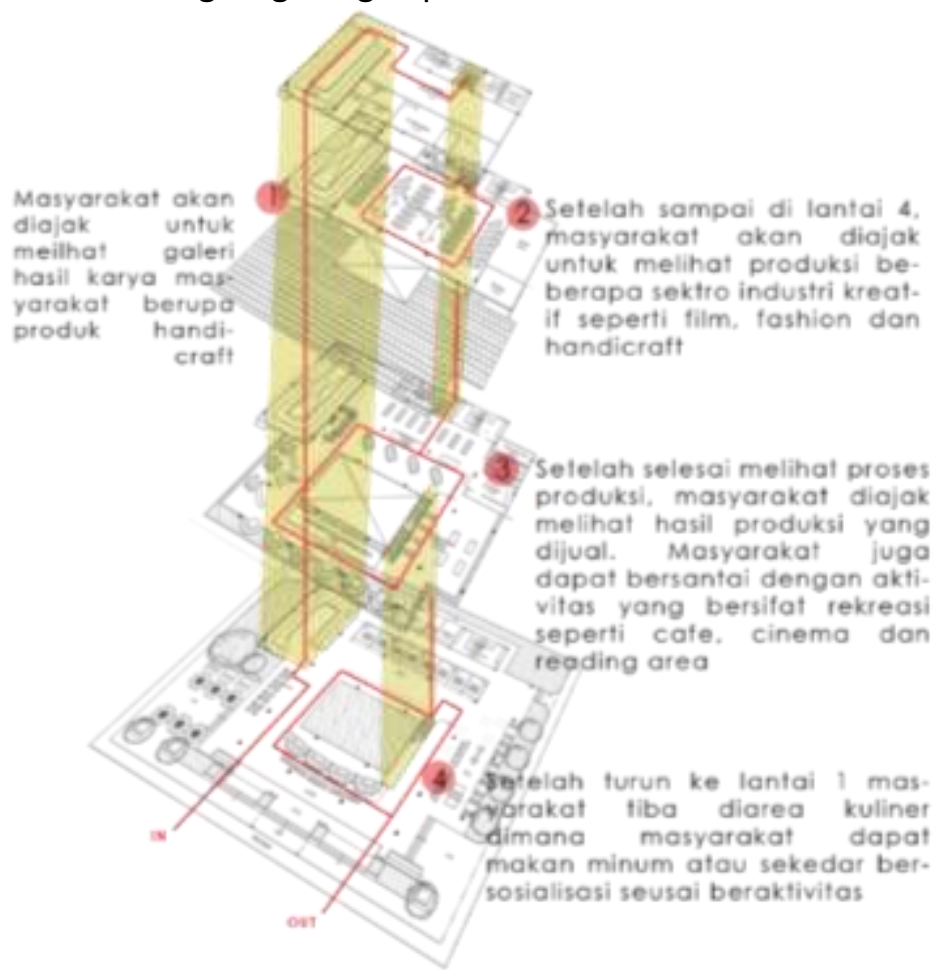

Gambar 11. Skema penerapan public viewing system Sumber: Penulis, 2020

Pada preseden INDOESTRI yang akan diambil adalah perancangan desain ruang workshop yang terbuka yang memungkinkan adanya interaksi antar pengguna dari kegiatan yang berbeda. Poin lain yang akan diambil ialah pengaturan penggunaan ruang yang maksimal dimana pada Senin hingga Jumaat mereka gunakan untuk para member sementara untuk hari Sabtu digunkan untuk kursus.
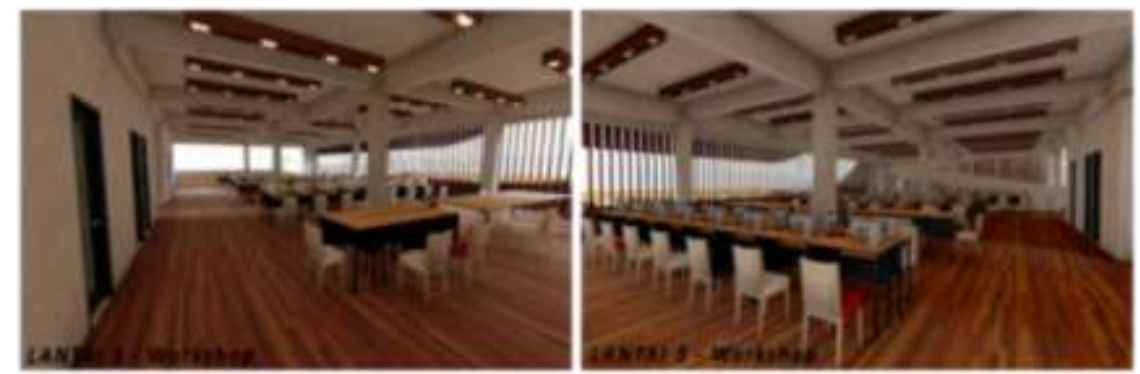

Gambar 12. Area workshop komunal

Sumber: Penulis, 2020

Dari preseden 8th Street Market, poin penting yang akan diambil ialah penggabungan aktivitasnya. Dimana mereka melakukan penggabungan area makan dengan area bermain hingga menghasilkan ruang yang berkesan fun dan tidak demanding terhadap pengunjungnya. 


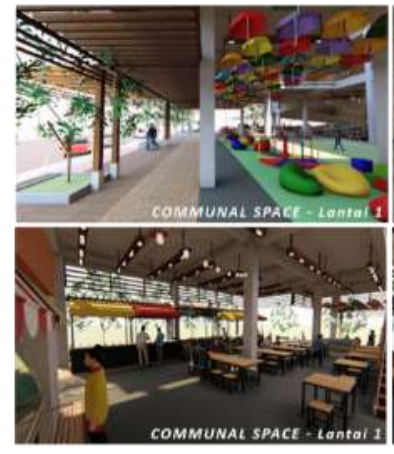

Gambar 13. Penerapan penggabungan area bermain dan kuliner Sumber: Penulis, 2020

Kemudian untuk penempatan fungsi program rancangan pada tiap lantai didasarkan pada frekuensi kehadiran masyarakat dalam menggunakan rancangan. Dimana pada lantai dasar akan diletakan program fungsi yang mengakomodir frekuensi masyarakat yang lebih luas, sementara peletakan program fungsi pada lantai teratas merupakan program dengan frekuensi masyarakat yang lebih minim. Oleh karena itu program rekreasi diletakan pada lantai dasar dan lantai dua, sementara program edukasi pada lantai tiga dan empat. Sebagai jawaban terhadap konsep rancang bangunan yang memiliki efisiensi terhadap penggunaan energi listrik, pada bangunan terutama pada lantai program rekreasi relative dibuat terbuka dengan penggunaan dinding masif untuk bagaian servis. Dengan cara ini aliran pengudaraan alami dapat mengalir dengan baik. Untuk lantai tiga dan empat, dibuat lebih tertutup dibanding lantai dasar dan dua sebagai respons pada diperlukannya fungsi ruang untuk kegiatan pelatihan. Namun untuk mengatasi aliran pengudaraan alami agar dapat masuk ke area workshop, penutup massif massa bangunan dibentuk dengan penggunan skin bangunan yang memilik celah sehingga aliran udara alami dapat masuk tanpa terlalu terhalangi.

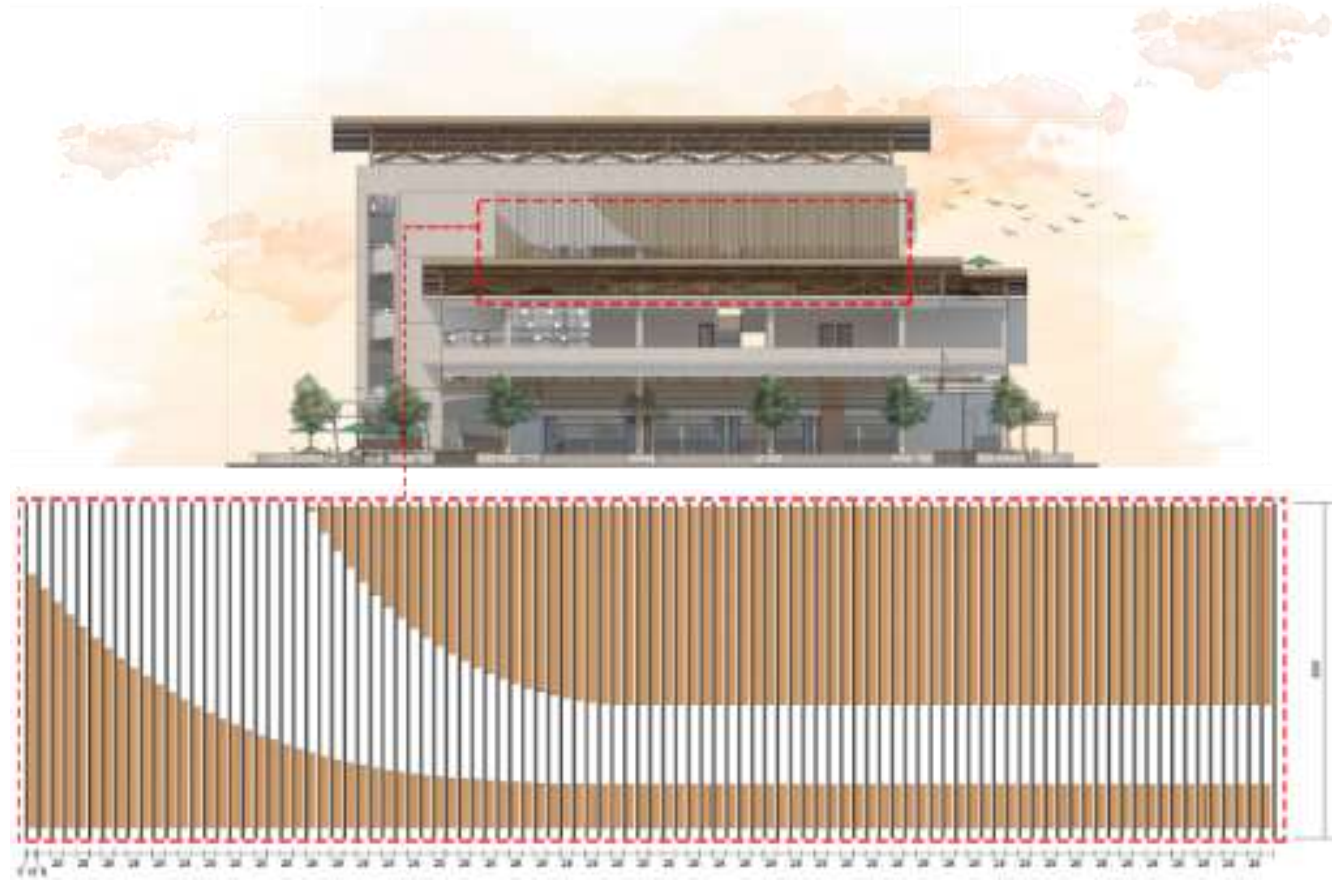

Gambar 14. Desain skin bangunan yang memungkinkan aliran udara

Sumber: Penulis, 2020

Penggunaan roster pada badan bangunan juga sebagai respons terhadap kebutuhan aliran udara sekaligus sebagai material yang lebih bersifat lokal. Bangunan juga memiliki kisi kisi pada 
bagian atas sehingga udara panas tidak tertahan pada bagian bawah atap melainkan dapat keluar melalui kisi kisi. Dengan kondisi iklim tropis di Indonesia bentuk dan jenis atap dipilih menggunakan atap yang memiliki kemiringan bukan dengan atap dak beton. Material atap menggunakan bitumen dengan pertimbangan kondisi atap yang akan diterjang hujan dan panas bergantian sehingga tidak dapat menimbulkan korosi. Selain itu material bitumen juga relative mudah dipasangan dan memiliki bobot yang ringan sehingga penggunaan konstruksi yang lebih ringan akan berdampak pada penurunan biaya pembangunan.

\section{KESIMPULAN DAN SARAN Kesimpulan}

Creative Recreative Place ini dinilai dibutuhkan masyarakat sekitar sebagai wadah kegiatan interaksi masyarakat yang selama ini belum didapatkan. Tempat ini akan menjadi tempat bgai masyarakat untuk berekreasi sejenak dari pekerjaan dan keseharian mereka. Dari segi kebutuhan hiburan masyarakat, tempat ini menghadirkan area courtyard yang dapat digunakan menjadi tempat untuk mengadakan open cinema yang akan memberikan tontonan hiburan tanpa biaya bagi masyarakat saat akhir pekan. Rancangan juga terdapat area membaca yang mengakomodir masyarakat, mulai dari anak anak hingga orang dewasa. Selain sebagai tempat rekreasi, tempat ini juga berfokus pada rancangan yang mampu meningkatkan kondisi perekonomian masyarakat salah satunya dengan memberikan area kuliner yang dikhususkan bagi pengembangan usaha kecil mikro masyarakat dan juga kegiatan pemberdayaan masyarakat melalui kegiatan workshop. Dengan adanya program pelatihan ini diharapkan masyarakat dapat menambah kemampuan mereka dalam berwirausaha serta menjadikan masyarakat yang mandiri dari segi perekoomiannya, sehingga berdampak pada penurunan angka pengangguran serta peningkatan taraf hidup masarakat itu sendiri. Selain itu untuk kedepannya diharapkan lahir para tenaga terampil baru dari tempat ini, sehingga fasilitas ini juga dapat menjadi ajang untuk memperkenalkan diri dan juga karya pada masyarakat luas.

\section{Saran}

Saran untuk pengembangan studi dan desain kelanjutanya yaitu memperdalam mengenai permasalahan dalam masyarakat dengan metode lain seperti kuisioner untuk memperluas cakupan masyarakat yang memberi input kepada perancang dan juga perlu mempersiapkan lebih banyak studi kasus lapangan mengenai proyek sejenis lebih awal dikarenakan adanya keterbatasan waktu dan perijinan untuk melakukan studi lapangan pada proyek sejenis tertentu.

\section{REFERENSI}

Badan Pusat Statistika DKI Jakarta. (2020). Kota Jakarta Pusat Dalam Angka. Diakses 4 Febuari 2020, <https://jakpuskota.bps.go.id/>

Bertels, C. (2019). Decoding Third Place.Arkansas: University of Arkansas

Fadem, C 2017. (2020). Third places count. Diakses 2 Febuari 2020, $<$ https://www.boardandvellum.com/blog/third-places-count/ $>$

Kartasasmita, G. (1995). Pemberdayaan Masyarakat Sebuah Tinjauan Administrasi. Pidato Pengakuan Jabatan Guru Besar Dalam IImu Administrasi Pada Fakultas Ilmu Administrasi. Malang: Universitas Brawijaya.

Oldenburg, R. (1999). The Great Good Place. New York: Marlowe \& Company

Suhendra. (2006). Peranan Birokrasi dalam Pemberdayaan Masyarakat. Bandung: Alfabeta.

Widjaja, H. (2003). Otonomi Desa Merupakan Otonomi Asli Bulat dan Utuh. Jakarta: PT. Raja Grafindo Persada. 
